\title{
Islamic Self-Identity Formation Through Language Learning: A Study of Religious Secondary School Students in Malaysia
}

\author{
Mohd Nazri Latiff Azmi ${ }^{1}$, Isyaku Hassan ${ }^{1}$, Engku Muhammad Tajuddin Engku Ali ${ }^{1}$, Ahmad Taufik Hidayah \\ Abdullah $^{1}$, Mohd Hazli bin Yah@Alias ${ }^{1}$, Muzammir bin Anas ${ }^{1} \&$ Nur Izzati Suhaimi ${ }^{1}$ \\ ${ }^{1}$ Faculty of Languages and Communication, Universiti Sultan Zainal Abidin Gong Badak Campus, 21300 Kuala \\ Nerus, Terengganu, Malaysia \\ Correspondence: Isyaku Hassan, Faculty of Languages and Communication, Universiti Sultan Zainal Abidin, \\ Gong Badak Campus, 21300 Kuala Nerus, Terengganu, Malaysia. E-mail: isyaku87@gmail.com
}

Received: January 7, 2021 Accepted: February 15, 2021 Online Published: February 21, 2021

doi:10.5539/ells.v11n1p38 URL: https://doi.org/10.5539/ells.v11n1p38

\begin{abstract}
Self-identity formation becomes increasingly challenging for students as they are exposed to different norms in the school environment. Education, language, and religion are crucial in the process of self-identity formation. Therefore, this study aims to explore how English language learning and the school environment influence Islamic self-identity formation among students in selected religious secondary schools in Terengganu, Malaysia. The study employed a qualitative approach in which 90 religious secondary school students in the State of Terengganu were selected using a purposive sampling technique. Focus group interviews were used as a data-gathering instrument. The students were divided across different sessions to ease the process of data collection. The data were transcribed and analyzed using inductive thematic analysis. The study found that English language learning does not influence the students' Islamic self-identity formation negatively. Instead, certain morals such as respect, self-esteem, and cooperation, are instilled in the students' self-identity. This study provides evidence on the students' ability to construct Islamic self-identity despite the challenges of second language learning.
\end{abstract}

Keywords: Islamic identity, language learning, Malaysia, religious schools, self-identity theory

\section{Introduction}

Students' identity in Second Language Education (SLE) has become a topic of concern in recent years (Menard-Warwick, 2005; Block, 2007; Morgan, 2007; Clarke, 2008; Lin, 2008; Alali, Ab Rashid, \& Al-Smadi, 2020). Identity formation relies on a range of primary social-communicative means through which personalities are formed, preserved, or resisted (Morgan \& Clarke, 2011). By belonging to a particular established community, teachers and students are presumed to hold specific personalities and language habits "whose estimated proximity or distance from the target language and culture serves to explain failure or success" in Second Language Acquisition (SLA) (Morgan \& Clarke, 2011, p. 820). According to Morgan and Clarke (2011), pedagogical interferences are directed exclusively toward changing the attributes of students and teachers.

The complexity of identity (Norton, 2000; Tsui, 2007), especially that of teachers and students which becomes of great concern, suddenly takes on a new significance in understanding the dynamics of the second language classroom (Morgan, 2004). Thus, this area becomes a potential opportunity for pedagogical research and focus on second language teaching and learning (Varghese, Morgan, Johnston, \& Johnson, 2005; Brogden \& Page, 2008). Associated with this new focus is a keen interest in the contexts and ways in which socio-cultural changes impact how the identity of teachers and students are formed in professional contexts (Johnson, 2006; Aziz, Zainudin, \& Ab Rashid, 2020). The relationship between individual and social identity formations represents the commonly perceived influences of varied sociopolitical aspects in what originally appears to be educational dimensions of identity (Clarke, 2008).

Perhaps, the most significant development regarding identity in second language research is the turn toward morals, values, and beliefs as well as their impact on teachers and students (Hafernik, Messerschmitt, \& Vandrick, 2002; Johnston, 2003; Crookes, 2009; Ab Rashid, Yunus, Azmi, Rahman, \& Yusoff, 2016) and how these elements could influence decision-making in second language curriculum development (Stritikus \& Varghese, 2005; Ramanathan \& Morgan, 2007; Farrell \& Tan, 2008). In developing indigenous identity, 
increased concerns about religion and loss of native languages are most often raised as existential threats (Hornberger, 2006). One of the most important questions, which requires context-specific responses, relates to how teaching and learning of a second language influence religious identity formation as well as indigenous languages of teachers and students, given the diversity of culture in contemporary society. This question reconfirms the need for continuous critical reflection amongst language experts concerning professional inclinations toward solutions for social and pedagogical problems.

The contemporary Muslim youth identity needs to be understood in terms of Islamic values and educational needs (Franz, 2007; Dewi, 2011). This is because students, in particular, are exposed to different norms, especially through secular public education (Janson, 2012). Therefore, this study focuses on Islamic self-identity formation among Muslim learners of English as a Second Language (ESL). The study aims to explore how English language learning and the school environment influence Islamic self-identity formation among students of selected religious secondary schools, particularly in the state of Terengganu, Malaysia. The study focuses specifically on the students' perceptions of English language learning, school environment, and Islamic self-identity. This is because preserving the identity of the next generation of Muslims is a fundamental question for the rapidly growing Islamic communities (Janson, 2012; Utaberta, Othman, Yazid, Yunos, Ismail, \& Ismail, 2015; Abdullah \& Nasir, 2017).

\section{Islamic Identity Formation}

Significant areas of interest in SLE have emerged (Morgan \& Clarke, 2011). The domain of religion represents one of the most contentious areas (Smith, 2007; Morgan \& Clarke, 2011; Borisov, Akaeva, \& Kazieva, 2016). Some education experts argue that the association between language, religion, and culture has become an ideological means of discrimination against religions in general and Islam in particular (Kumaravadivelu, 2008; Scott, 2007). Other scholars questioned the possibility and desirability of hiding this dimension of identity in SLE contexts. They discovered the expressed interdictions against religious identity in SLE as rather two-faced, considering the current concern about identity (Baurain, 2007). Nevertheless, Muslims become increasingly conscious of their identity and its reflection (Brown, 2006; Abdullah \& Nasir, 2017). There are constant changes in the collective articulation of community, identity, and traditions in Muslim society.

Previous studies have investigated the issue of identity formation from various perspectives and dimensions. For example, Rissanen (2014) conducted a case study to examine different ways of supporting the development of Muslim students' identities in the classroom. According to the study, teachers demonstrated their belief in collective Muslim identity, and hence promoted unity in the heterogeneous class. A study conducted by Milligan (2003) also found that most teachers in the Philippines believe Islam is a complete way of life, which signifies the influence of Islamic identity on education. The assertions of Islamic identity among teachers offer different but interrelated levels of meaning regarding commitments for Islamic identity formation. Dewi (2011) examined identity formation among female Muslim youths in Indonesia through literature. The author argued that literature studies could be useful in revealing the identity formation among young Indonesian female Muslims, considering the type of books they read. Some authors have started to produce literature specifically for the English-speaking Muslim audience (Janson, 2012).

Additionally, Miedema (2014) investigated the contribution of schools to the process of educational relations amongst experts of students' identity formation. Also, a study conducted by Hassen (2013) focused on the conceptualization of the dialectical relationship between religious education and identity formation in Islamic schools, particularly in Australia. The study explored how schooling relates to the development of Islamic identity formation. The study found a complex relationship between religion, Islamic identity formation, and educational politics. Selçuk (2013) argued that though some researchers have made a significant contribution toward the issue of Islamic identity formation in the educational sector, they were unable to transform the teaching and learning environments. According to the author, there is a need for a language through which one can enter the public sphere religiously.

Moreover, Schmidt (2004) explored the formation of transnational identity among Muslim adolescents in Denmark, Sweden, and the US. The findings indicated that transnational Muslim identity formation faces great challenges in the West, particularly concerning the environments and regulations of the host countries. Similarly, Omar (2012) noted that Islamic identity formation faces challenges, especially in multicultural and predominantly secular societies. In a particular context, Franz (2007) investigated the relationship between politics of discrimination, relative deprivation, and identity formation among Muslim youths in Europe. The author argued that many Muslims entrench themselves in segregated, secluded, separate divisions, and groups alienated from their immediate societies because of political and socioeconomic circumstances in their countries 
other than religious motives.

Furthermore, Omar (2012) evaluated Islamic identities in the diverse context of Canada. According to the study, Muslims and religious societies face significant challenges in maintaining their values and practicing some of their religious duties. Also, a study conducted by Borisov et al. (2016) focused on the forms of religious identity in the self-consciousness of contemporary Dagestan youths. According to the study, the actualization process of Islamic identity is particularly active in Dagestan. Nonetheless, despite an increase in the number of Islamic secondary schools, Islamic literature, and mosques, the level of religious consciousness among Muslim youths remains significantly low. Similarly, Abu-Ras, Senzai, and Laird (2013) used interviews to study how the September 11, 2001 attacks changed the collective identity among American Muslim physicians. The findings showed that the preconception faced by many Muslims has affected their sense of identity.

Based on the above findings, there is a need to focus on the development of Islamic self-identity formation in second language learning. Nonetheless, it is worthy of note that a second language can be adopted and decolonized to serve indigenous needs and interests (Mahboob, 2009). Given the importance of the secondary school environment in developing identities and socio-cultural values (Janson, 2006), this study focuses on Islamic self-identity formation, particularly in second language learning. Identity shapes peoples' standard of judgment by providing them with a horizon within which value discriminations are possible (Kosebalaban, 2005). Therefore, the findings of this research are expected to provide educationists and relevant authorities with valuable insights on how to discover a more creative approach to developing the students' Islamic self-identity.

\section{Theoretical Approach}

This study adopts the social identity theory developed by Henri Tajfel and John Turner during the 1970s. The theory suggests that people's behaviors can be changed through modification of their self-identity or some aspects of their self-concept which are derived from knowledge and emotional attachment to a particular group. According to social identity theory, interpersonal behavior is mainly determined by individual characteristics and interpersonal interactions (Tajfel \& Turner, 1979). The basic assumption in this theory is that an individual is inherently motivated to achieve positive distinctiveness and that individuals struggle to preserve their positive identity. The concept of identity refers to continuity in the sense of self within an individual (Horowitz, 2012).

Although social identity theory focuses on people's behavior, it encompasses some fundamental socio-cognitive processes associated with identity-related behavior (McCall \& Simmons, 1978). Social identity theory suitably articulates the fundamental socio-cognitive processes of categorization and self-enhancement with "subjective belief structures". Categorization improves intergroup restrictions by creating group-distinctive stereotypical and normative perceptions and actions. It also allocates people to relevant contextual categories. Categorization functions on both social and non-social motivations to highlight and emphasize areas of experience that are personally important in a specific context (Abrams \& Hogg, 1990).

\section{Methodology}

This study employed a qualitative approach in which 90 religious secondary school students in the State of Terengganu were selected using a purposive sampling technique. Focus group interviews were used as a data-gathering instrument. The students were divided across different sessions to ease the data collection process. It is generally recommended that six to ten (MacIntosh, 1993) or even fifteen respondents (Goss \& Leinbach, 1996) could be included in a focus group interview per session. The respondents were selected from five religious institutions consisting of one urban school (Sultan Zainal Abidin Secondary School), one suburban school (Imtiaz Secondary School), one rural school (Setiu Secondary School), and two sub-rural schools (Durian Guling Secondary School \& Marang Secondary School). The respondents consisted of 39 male students and 51 female students. A semi-structured interview was conducted in separate sessions with each session consisting of either male or female students exclusively based on the common practice in Islamic religious secondary schools. All collected data were transcribed and analyzed using inductive thematic analysis.

The same questions were designed and administered to all the interviewees. In this regard, Sewell (2008) asserted that semi-structured interviews are useful in reducing bias when comparing different responses. The interview flow was based on predetermined questions, but the respondents were allowed to expand their responses. Besides, precise questions were asked for clarification of any exciting information that might arise in the process of conducting the interviews. These questions enabled the students to respond freely and provide in-depth explanations and clarifications. Semi-structured interviews are useful as they explore the actual responses of participants while providing various viewpoints regarding the research topic. They provide a complex picture of the situation and generate certain information that may not be anticipated by the researcher (Creswell, 2012). 
The interview responses were analyzed using the comparatively generalized four stages of interview data analysis proposed by Cohen, Manion, and Morrison (2007): Generating natural units of meaning; labeling, categorizing, and ordering the natural units; constructing narratives to define the interview data; and interpreting the interview data. According to Cohen et al. (2007), qualitative data analysis is almost inevitably interpretive because it is a less accurate representation compared to numerical analysis. The data were inductively coded by reading through the text, identifying, classifying, and interpreting emerging themes based on the information given by the participants. Each explanation, comment, opinion, or argument was critically interpreted and evaluated. Only relevant information was coded and analyzed.

\section{Findings}

This study aims to explore how English language learning and the school environment influence Islamic self-identity formation among students in selected religious secondary schools. The respondents consist of 90 students selected from five religious secondary schools in Terengganu, Malaysia. This selection was based on the respondents' willingness to participate in the research. The analysis was performed based on themes that emerged from the interview responses. The first question was purposefully broad, which allows the researchers to obtain a general sense of the interviewees' perceptions of their Islamic self-identity in the learning process. The students were asked to express their views regarding what influences their Islamic self-identity in the language learning process. Table 1 presents emerging themes from the students' responses.

Table 1. What influences the students' Islamic self-identity

\begin{tabular}{|c|c|c|}
\hline Questions & Themes & Exemplary quotes \\
\hline \multirow[t]{5}{*}{$\begin{array}{l}\text { Based on your experience, what } \\
\text { influences your Islamic self-identity in } \\
\text { the learning process? }\end{array}$} & School environment & $\begin{array}{l}\ldots \text { teachers play a big role in shaping our self-identity. } \\
\ldots \text { if we were not exposed to the Quran at this stage, a good self-identity can't } \\
\text { be formed. } \\
\ldots \text { when we get along with good people, we start to change for the better... } \\
\text { Schools play an important role and make a huge impact on shaping our } \\
\text { identity and image.... } \\
\text { [At school] We learn more manners. We get more reminders and advice. }\end{array}$ \\
\hline & Parents at home & At an early age, while at home, parents gave us early exposure.... \\
\hline & Societal norms & $\begin{array}{l}\text {... the norms of society play an essential role. For example, the norms of } \\
\text { Malay people; wearing Baju Melayu and Songkok. }\end{array}$ \\
\hline & Community & The surroundings also play their part.... \\
\hline & $\begin{array}{l}\text { Individual's principles } \\
\text { and beliefs }\end{array}$ & $\begin{array}{l}\ldots \text { one's self-identity is not going to change if one has strong principles and } \\
\text { beliefs. }\end{array}$ \\
\hline
\end{tabular}

As represented in Table 1, the students feel that their Islamic self-identity is influenced by the school environment, parental care at home, societal norms, community, and individual principles and beliefs. Besides, the students believe that performing the five "daily prayers", respecting others, helping others, being polite, and wearing proper Islamic attire constitute part of Islamic identity. The students stated that, in the school environment, they learned how to wear proper Islamic attire, dare to impede wrongdoings, talk politely, and have exemplary behavior. This situation demonstrates the complexity of Islamic identity formation. The secondary school environment plays a significant role in students' life because youth is an important stage of identity development that occurs in various aspects, scopes, and dimensions (Franz, 2007; Dewi, 2011). Table 2 shows the students' perceptions of English language learning and its influence on their Islamic self-identity formation.

Table 2. Influence of English language

\begin{tabular}{lll}
\hline Questions & Themes & Exemplary quotes \\
\hline $\begin{array}{l}\text { What is your opinion on this } \\
\text { statement? Students who master } \\
\text { the English language have a } \\
\text { personality similar to the western. }\end{array}$ & Not the main factor & $\begin{array}{l}\text {.. it depends on the individual's faith and belief eventually } \\
\text { It depends on the individual and other factors.... }\end{array}$ \\
& Not influential & $\begin{array}{l}\text { Even though a student learns and masters the English Language, he } \\
\text { may have a strong Islamic value in himself... }\end{array}$ \\
& $\begin{array}{l}\text { Might be through imitation } \\
\text { Might be due to a lack of } \\
\text { religious education } \\
\text { Feeling proud }\end{array}$ & $\begin{array}{l}\text { English language female teachers do not wear Hijab... } \\
\ldots \text { perhaps it is due to lack of religious exposure and education but } \\
\text { it is surely not mainly because of the language learned or spoken. } \\
\end{array}$ \\
\hline
\end{tabular}


As shown in Table 2, emerging themes from the students' responses indicate that English language learning does not influence their Islamic self-identity formation. They believe that this kind of influence could be possible through imitation of the teachers' mode of dress or due to lack of religious education. The quality of self-identity "rests on the individual's belief, even if there are changes or foreign elements in the surroundings". English language learners may develop personalities similar to western traits due to certain factors such as the environment and mode of dress, not necessarily the language used or learned. Various factors such as the surrounding and societal norms could influence the individual's Islamic self-identity (Omar, 2012; Borisov et al., 2016). According to the students' responses, English is "merely a language", and a negative influence on Islamic self-identity occurs due to other factors "not mainly because of the language learned or spoken". The students opined that some English students do not take any of the Islamic subjects, such as Usuluddin (fundamentals of Islam), Hadith (Prophetic traditions), and Quran, but they are still well-mannered and have strong Islamic self-identity. However, the students believe that those who master the English language feel proud of themselves.

\section{Discussion}

The findings reported in this study showed that English language learning has no negative influence on Islamic self-identity formation. Instead, students develop certain moral values, such as self-esteem and cooperation in learning the English language. Therefore, English language learning could be influential in developing students' self-identity and moral values. Besides, Islamic self-identity formation among students is influenced by the school environment. These findings concur with a few previous studies on Islamic self-identity (Dewi, 2011; Rissanen, 2014). In Malaysia, identities are likely to be preserved due to the restrictive nature of the environment and the people's unique cultural background (Utaberta, 2015). Also, the people of Terengganu, by nature, hold their culture and religious inclination (Abdullah \& Nasir, 2017). According to social identity theory, an individual is inherently motivated to achieve positive distinctiveness (Tajfel \& Turner, 1979; Abrams, \& Hogg, 1990).

Muslims become increasingly conscious of their identity to face the challenges of the global religious identity crisis (Brown, 2006). For instance, there is a concern that second language teachers and learners can be "westernized" or "religionized". This concern is based on the historic association of English with colonialism and Christianity as the global demand for English rises. This argument is problematic not only for students but also second language professionals who self-identify as Muslims. Given the perceived association of English with westernization and colonial power, "many SLE researchers have debated how English should be taught in Islamic societies" (Morgan \& Clarke, 2011, p. 828).

Identity shapes peoples' level of judgments by providing a prospect in which value judgments are feasible (Kosebalaban, 2005). In essence, Muslims' culture has been redefined to incorporate the Muslims' habits and customs around the globe. Part of the result of this change in identity development is the declaration of women's rights within Islamic societies. This affirmation is accomplished by largely separating culture from religion (Brown, 2006). The newly designed policy of Sukan Malaysia (Malaysian Sports) organization emphasizes the issue of Aurat (nakedness) and this practice provides an example of good cultivation of self-identity values. The objective of this policy could be achieved by widening the students' thinking horizon beyond textbooks and instilling self-identity values. Besides, the Terengganu State Education Department has launched PKBM (Pasukan Kadet Bersatu Malaysia/Malaysian United Cadet Corps) to encourage students toward language mastery and identity formation through games and other activities within the community.

\section{Conclusion}

This study explored how English language learning and the school environment influence Islamic self-identity formation among students in selected religious secondary schools in Malaysia. The findings revealed that English language learning has no negative influence on students' Islamic self-identity formation. Instead, students acquire certain morals such as respect, self-esteem, and cooperation in the learning of English. These findings indicate that English language learning could be an effective means of developing students' morals and enriching cultural values. Therefore, students tend to develop positive attitudes through language learning as opposed to the notion that second language learners are "brainwashed" or "westernized". Thus, English language learning can help students to develop positive self-identity.

The findings of this study advance our understanding of the relationship between the English language, environment, and Islamic self-identity. This study provides evidence on the students' ability to construct Islamic self-identity despite the challenges of second language learning and the school environment. Besides, this study could be beneficial to language instructors and education authorities by providing information that could be useful in the process of curriculum development, particularly for secondary schools. Positive learning outcomes could be achieved by broadening the students' intellectual ability through contact with self-identity morals 
beyond the scope of textbooks. This qualitative study is limited to secondary school students' Islamic self-identity, further research may focus on higher learning institutions.

\section{Acknowledgment}

This research is funded by the Special Research Grant Scheme (SRGS), Universiti Sultan Zainal Abidin, Malaysia.

\section{References}

Ab Rashid, R., Yunus, K., Azmi, N. J., Rahman, S. B. A., \& Yusoff, S. Z. (2016). The discursive construction of teachers' desirable identity on a social networking site. International Journal of Applied Linguistics and English Literature, 5(5), 139-144. https://doi.org/10.7575/aiac.ijalel.v.5n.5p.13

Abdullah, B., \& Nasir, B. M. (2017). Dakwah generates the arts of Malay heritage in Terengganu. International Journal of Academic Research in Business and Social Sciences, 7(8), 305-313. https://doi.org/10.6007/IJARBSS/v7-i8/3231

Abrams, D. E., \& Hogg, M. A. (1990). Social identity theory: Constructive and critical advances. New York: Springer-Verlag Publishing.

Abu-Ras, W., Senzai, F., \& Laird, L. (2013). American Muslim physicians' experiences since 9/11: Cultural trauma and the formation of Islamic identity. Traumatology, 19(1), 11-19. https://doi.org/10.1177/1534765612441975

Alali, O. M., Ab Rashid, R., \& Al-Smadi, O. A. (2020). Learner identity and interactional competence in English as a Foreign Language classroom. International Journal of English Language and Literature Studies, 9(3), 143-150. https://doi.org/10.18488/journal.23.2020.93.143.150

Aziz, A. A., Zainudin, W. W., \& Ab Rashid, R. (2020). Supporting English As a Second Language (ESL) Teachers' Professional Development Through Multi-Platforms' Online Affinity Space. Learning and Technology, 14(9), 258-264. https://doi.org/10.3991/ijim.v14i09.11158

Baurain, B. (2007). Christian witness and respect for persons. Journal of Language, Identity, \& Education, 6(1), 201-219. https://doi.org/10.1080/15348450701454221

Block, D. (2007). Second language identities. London: Continuum.

Borisov, R. V., Akaeva, N. S., \& Kazieva, N. N. (2016). Islamic Identity of the Russian North Caucasus Modern Challenges. European Journal of Science and Theology, 12(2), 165-175.

Brogden, L. M., \& Page, B. (2008). Ghosts on the cupboard: Discursive hauntings during the first year of French immersion teaching in Canada. In T. S. C. Farrell (Ed.), Novice language teachers: Insights and perspectives for the first year (pp. 118-131). London: Equinox Publishers.

Brown, K. (2006). Realising Muslim women's rights: The role of Islamic identity among British Muslim women. In Women's studies international forum (Vol. 29, pp. 417-430). Pergamon: University of York St John. https://doi.org/10.1016/j.wsif.2006.05.002

Clarke, M. (2008). Language teacher identities: Co-constructing discourse and community. Clevedon: Multilingual Matters. https://doi.org/10.21832/9781847690838

Cohen, L., Manion, L., \& Morrison, K. (2007). Research method in education. New York: Routledge. https://doi.org/10.4324/9780203029053

Creswell, J. W. (2012). Research design: Qualitative, quantitative and mixed methods approaches (2nd ed.). London: SAGE publications.

Crookes, G. (2009). Values, philosophies, and beliefs in TESOL: Making a statement. Cambridge: Cambridge University Press.

Dewi, N. (2011). Formation of Youth Identity in Indonesian Islamic Chick Lit. $k @ t a:$ A Biannual Publication on the Study of Language and Literature, 13(1), 134-146. https://doi.org/10.9744/kata.13.1.134-146

Farrell, T. S. C., \& Tan, S. (2008). Language policy, language teachers' beliefs and classroom practices. Applied Linguistics, 29(3), 381-403. https://doi.org/10.1093/applin/amm050

Franz, B. (2007). Europe's Muslim youth: An inquiry into the politics of discrimination, relative deprivation, and identity formation. Mediterranean Quarterly, 18(1), 89-112. https://doi.org/10.1215/10474552-2006-036

Goss, J. D., \& Leinbach, T. R. (1996). Focus groups as alternative research practice: Experience with 
transmigrants in Indonesia. Area, 28(2), 115-123.

Hafernick, J. J., Messerschmitt, D. S., \& Vandrick, S. (2002). Ethical issues for ESL faculty: Social justice in practice. Mahwah, NJ: Lawrence Erlbaum Associates.

Hassen, Y. (2013). Making Muslims: The Politics of Religious Identity Construction and Victoria's Islamic Schools. Islam and Christian-Muslim Relations, 24(4), 501-517. https://doi.org/10.1080/09596410.2013.813120

Hornberger, N. (2006). Voice and biliteracy in indigenous language revitalization: Contentious educational practices in Quechua, Guarani, and Maori contexts. Journal of Language, Identity, \& Education, 5(1), 277-292. https://doi.org/10.1207/s15327701jlie0504_2

Horowitz, M. J. (2012). Self-identity theory and research methods. Journal of Research Practice, 8(2), M14-M14.

Janson, T. (2012). Imaging Islamic Identity: Negotiated Norms of Representation in British-Muslim Picture Books. Comparative Studies of South Asia, Africa and the Middle East, 32(2), 323-338. https://doi.org/10.1215/1089201X-1628962

Johnson, K. (2006). The sociocultural turn and its challenges for second language teacher education. TESOL Quarterly, 40(1), 235-257. https://doi.org/10.2307/40264518

Johnston, B. (2003). Values in English language teaching. Mahwah, NJ: Lawrence Erlbaum Associates. https://doi.org/10.4324/9781410606983

Kosebalaban, H. (2005). The impact of globalization on Islamic political identity: The case of Turkey. World Affairs, 168(1), 27-37. https://doi.org/10.3200/WAFS.168.1.27-37

Kumaravadivelu, B. (2008). Cultural globalization and language education. New Haven: Yale University Press.

Lin, A. M. Y. (Ed.). (2008). Problematizing identity: Everyday struggles in language, culture, and education. New York: Taylor \& Francis.

MacIntosh, J. A. (1993). Focus groups in distance nursing education. Journal of Advanced Nursing, 18(12), 1981-1985. https://doi.org/10.1046/j.1365-2648.1993.18121981.x

Mahboob, A. (2009). English as an Islamic language: A case study of Pakistani English. World Englishes, 28(2), 175-189. https://doi.org/10.1111/j.1467-971X.2009.01583.X

McCall, G. J., \& Simmons, J. L. (1978). Identities and Interactions. New York: The Free Press.

Menard-Warwick, J. (2005). Both a fiction and an existential fact: Theorizing identity in second language acquisition and literacy studies. Linguistics and Education, 16(3), $253-274$. https://doi.org/10.1016/j.linged.2006.02.001

Miedema, S. (2014). "Coming out religiously!" Religion, the public sphere, and religious identity formation. Religious Education, 109(4), 362-377. https://doi.org/10.1080/00344087.2014.924753

Milligan, J. A. (2003). Teaching between the cross and the crescent moon: Islamic identity, postcoloniality, and public education in the Southern Philippines. Comparative Education Review, 47(4), 468-492. https://doi.org/10.1086/379494

Morgan, B. (2007). Poststructuralism and applied linguistics: Complementary approaches to identity and culture in ELT. In J. Cummins \& C. Davison (Eds.), International handbook of English language teaching (Vol. 2, pp. 949-968). Norwell, MA: Springer Publishers. https://doi.org/10.1007/978-0-387-46301-8_69

Morgan, B., \& Clarke, M. (2011). Identity in second language teaching and learning. In E. Hinkel (Ed.), Handbook of research in Second Language Teaching and Learning (pp. 817-836). New York: Routledge.

Norton, B. (2000). Identity and language learning: Gender, ethnicity and educational change. Singapore: Pearson Education.

Omar, A. A. (2012). Islamic identity in the Canadian multicultural context. Cultural and Pedagogical Inquiry, 3(2). https://doi.org/10.18733/C3NP4C

Ramanathan, V., \& Morgan, B. (2007). TESOL and policy enactments: Perspectives from practice. Introduction to the special issue on language policy. TESOL Quarterly, 41(3), 447-463. https://doi.org/10.1002/j.1545-7249.2007.tb00080.x

Rissanen, I. (2014). Developing religious identities of Muslim students in the classroom: A case study from 
Finland. British Journal of Religious Education, 36(2), 123-138. https://doi.org/10.1080/01416200.2013.773194

Schmidt, G. (2004). Islamic identity formation among young Muslims: The case of Denmark, Sweden and the United States. Journal of Muslim Minority Affairs, 24(1), 31-45. https://doi.org/10.1080/1360200042000212223

Scott, J. (2007). The politics of the veil. Princeton, NJ: Princeton University Press. https://doi.org/10.1515/9781400827893

Selçuk, M. (2013). Academic expertise, public knowledge, and the identity of Islamic Religious Education. Religious Education, 108(3), 255-258. https://doi.org/10.1080/00344087.2013.783313

Sewell, M. (2008). The use of qualitative interviews in evaluation. Tucson, AZ: The University of Arizona.

Smith, D. (2007). Spirituality and language pedagogy. In D. Smith \& T. Osborn (Eds.), Spirituality, social justice, and language learning (pp. 13-29). Charlotte, NC: Information Age Publishing.

Stritikus, T., \& Varghese, M. (2005). "Nadie me dijo (Nobody told me)": Language policy negotiation and implications for teacher education. Journal of Teacher Education, 56(1), 73-87. https://doi.org/10.1177/0022487104272709

Tajfel, H., \& Turner, J. C. (1979). An integrative theory of intergroup conflict. In W. G. Austin \& S. Worchel (Eds.), The social psychology of intergroup relations (pp. 33-47). Monterey, CA: Brooks/Cole.

Tsui, A. (2007). Complexities of identity formation: A narrative inquiry of an EFL teacher. TESOL Quarterly, 41(4), 657-680. https://doi.org/10.1002/j.1545-7249.2007.tb00098.x

Utaberta, N., Othman, H., Yazid, M., Yunos, M., Ismail, N. A., \& Ismail, S. (2015). A Hadith Evaluation on the Identity, Design, Location and Space Planning of Modern Mosques in Malaysia. Adv. Environ. Biol., 9(95), 466-472.

Varghese, M., Morgan, B., Johnston, B., \& Johnson, K. A. (2005). Theorizing language teacher identity: Three perspectives and beyond. Journal of Language Identity \& Education, 4(1), 21-44. https://doi.org/10.1207/s15327701jlie0401_2

\section{Copyrights}

Copyright for this article is retained by the author, with first publication rights granted to the journal.

This is an open-access article distributed under the terms and conditions of the Creative Commons Attribution license (http://creativecommons.org/licenses/by/4.0/). 